\title{
Impacts of Service Sector Policy Reforms: CGE Model Analysis Based on Sri Lanka
}

\author{
PALLEGEDARA. A. \\ Graduate School of Policy Studies \\ National Graduate Institute for Policy Studies (GRIPS) \\ 7-22-1, Roppongi, Manato-ku, Tokyo \\ JAPAN \\ palle321@gmail.com
}

\begin{abstract}
: -
This paper investigates the macroeconomic effects of service sector reform policies using two computable general equilibrium models of Sri Lankan economy. The first model assumes a perfectly competitive market economy and second one assumes a monopoly supplier market economy. Both models have been calibrated using Sri Lanka's social accounting matrix currently available. Impacts of both service sector production tax reduction and import tariff increase have been simulated. Simulation results imply that reduction of service sector production tax is more productive and socially efficient than the increase of import tariff in both perfectly competitive market and monopoly supplier market economy. Reduction of service sector production tax seems to improve not only the service sector output but also the social welfare.
\end{abstract}

Key words-: Sri Lanka Service sector, Production Tax, Import tariff, CGE model

\section{Introduction}

Transformation to service sector is one of the important aspects of economic policies not only in the developed countries but also in developing countries. In high-income countries, on average, service sector constitute nearly two thirds of total gross domestic product (GDP). Among low and middle-income countries, they account for a smaller share of 54 percent but still the majority of the output. In East Asia, the service sector on average is about the same size as the industrial sector, at 41 percent of GDP. In Sri Lanka 59.3 percent of total GDP is contributed by service sector (Source: National 
Accounts 2009). Countries that have adapted service sector oriented development are reported to have higher rates of economic growth. Singapore, Hong Kong is two earlier examples and India is a good recent example for service sector oriented economic development.

Literature suggests that many countries identified the importance of service sector policy reforms. Turkey introduced neo-liberal policies to increase foreign direct investments (FDI) in various service sectors such as financial, producer and distributer services (Dilek 2002). China had changed its banking sector policies significantly in the period of 1985 to 2002. However, the impacts from these reforms had little impact on the Chinese banking sector (Xiaoqing \& Shelagh 2009). Brown et al. (2009) has also investigated the impacts from banking sector policy reforms in Kyrgyzstan. They found that banking service sector policy reforms have helped in macroeconomic stabilization. Gooroochurn and Milner (2005) analyzed the effects of tax reforms on tourism sector in Mauritius. Using computable general equilibrium model simulation results, they found that tourism sector tax reform is the most socially efficient method of increasing tax revenue.
Anzari (1995) has investigated the trend of service sector growth in India, Pakistan and Sri Lanka. According to his individual country, combined crosssection and time series analysis, service sector has secular trend in each country. Verma (2006) found that sharp increase of service sector growth following India's trade liberalization policy in 1991.

Current Sri Lankan government has recognized the importance of service sector to achieve a rapid economic development. Government has proposed various tax reductions for services such as banking, tourism, information technology, aviation (Sri Lanka Ministry of Finance and Planning 2010). Current Sri Lankan government policy is to become a dynamic global economic centre by developing Sri Lanka as a Naval, Aviation, Commercial, Energy and Knowledge hub (Government of Sri Lanka 2010). Sri Lanka has very good chance to enhance the service sector because Sri Lanka is situated in strategically important place in the Indian Ocean. Moreover, Sri Lankan labor force is highly educated compare to other South Asian nations. The main components of Sri Lanka's service sector are tourism, banking, finance, shipping, aviation and retail trade. 
Being situated as a small island country in northern part of Indian Ocean, It has a very good position to develop service sector. Sri Lankan government recently started to construct new international harbor and airport in Hambantota district to boost the shipping and aviation services. Financial services are another valuable sector which has got attention by global firms. Sri Lanka's financial services come under the purview of the Central Bank of Sri Lanka. Liberal policies and a lucrative business environment have made the island nation an attractive location for several global banking firms to set up operations, complementing a strong local network of investment and commercial banks. Central Bank recently relaxed forex controls in Sri Lanka by allowing Sri Lankan customers to open bank accounts overseas and buy stocks and shares of companies listed in international exchanges.

On the other hand, Sri Lanka's IT services have made rapid progress in the past decade, becoming a vibrant sector in the country and the region. The significant inroads has prompted growth and development in IT-related services as well as IT education. The sector has become particularly popular among the country's younger generation who have given prominence to improve their skills and knowledge in IT-related products and service. India's recent success as a global IT giant also gives valuable opportunity to develop information and communication technology (ICT) service in Sri Lanka.

The purpose of this paper is to examine the macroeconomic effects of service sector policy reforms. Thus, in this paper, I apply computable general equilibrium (CGE) model approach to Sri Lankan economy and look for new production tax and import tariff policies to improve the service sector productivity and efficacy in Sri Lanka. I use two CGE models based on perfectly competitive market economy and monopoly supplier market economy. I discuss the macroeconomic impacts of service sector policy reforms using several policy experiment simulations. In particular, I examine the effects on service sector total output, imports, exports and social welfare.

This paper is structured as follows. Section 2 discusses the methodology that I use in the analysis. The basic model structure and model calibration are discussed in this section. Section 3 presents the policy experiment simulation results based on CGE model approach. Section 4 discusses the 
simulation results. Finally section 5 concludes the paper.

\section{Methods}

To quantify the possible impacts of service sector tax policies in Sri Lanka, I employ a static computable general equilibrium model for Sri Lankan economy. Following Hosoe, Gasawa and Hashimoto (2010), two computable general equilibrium (CGE) models have applied to Sri Lankan economy. The first model assumes perfectly competitive market economy and second model assumes monopoly supplier market where each sector only has one supplier. Basically these models provide an internally consistent economy-wide framework for policy analysis, in considering internal and/or external shocks to an economy on macro and micro economic variables. CGE models have been using extensively to analyze general macroeconomic issues, fiscal policy issues, industrial and labor policy issues, environmental policy issues, and international trade policy issues. CGE models require relatively low data compare to econometric methods that widely used in the economic analysis. Thus, CGE models are extremely useful when we deal with developing economies because sufficient statistical data is not easily available in most developing countries.

\subsection{Model Structure}

The CGE model that I use in this paper includes four types of institutions: households, firms, the government and the rest of the world. Production sectors categorized in to Agriculture, Manufacturing and Service sectors. The government collects taxes (income taxes and tariffs), purchases goods and services, and provides transfers to household groups or firms. The economy is also involved in transactions with the rest of the world: exporting or importing goods and services, receiving or sending transfers and grants. Household owns the capital and labor. Labor is divided in to 2 categories; skilled labor and unskilled labor. The separation of skilled and unskilled labor is based on occupational classifications. The skilled labor is assumed to consist of managers, administrators, professionals, and para-professionals. The sales persons, clerks, trade-persons, plant and machine operators, drivers, laborers, and farm workers comprise the unskilled labor category.

All the agents of the model maximize their objectives. While Households maximize their utility, producers maximize their profit. Firms optimize 
labor according to wage, equalizing the value of the marginal product of labor with its wage rate. While basic structure for both perfectly competitive market economy model and monopoly market economy model are same, in the latter model consider each sector has only one monopoly supplier. The basic structure of service sector model is given in figure 1 and the description of model variables is shown in table 1 .

The model has six stages. First, capital and labor (unskilled and skilled) are aggregated into composite factor with the composite factor production function. I assume Cobb-Douglas type of composite factor production function which allows substitution between labor and capital. Second, the composite factor is combined with the intermediate inputs in the service sector to produce the gross domestic output of service sector using gross domestic output production function. I assume Leontief type of gross domestic production function which does not allow substitution among intermediate inputs and composite factor. Third, the gross domestic output is divided into exports and the domestic good with the gross domestic output transformation function. I assume constant elasticity of transformation (CET) type of gross domestic output transformation function. In the forth stage, the domestic good is combined with the imports to produce the composite good using composite good production function. I assume constant elasticity of substitution (CES) type composite good production function. Also I assume imperfect substitution between imports and the domestic goods which is called Armington's (1969) assumption. Fifth, the composite good is distributed among the household's consumption, the government consumption, investment purposes, and intermediate input usage according to composite good market equilibrium. Finally, household's utility is generated by consuming service sector composite good, agriculture sector composite good and manufacturing sector composite good. I assume households have Cobb-Douglas type utility function. 


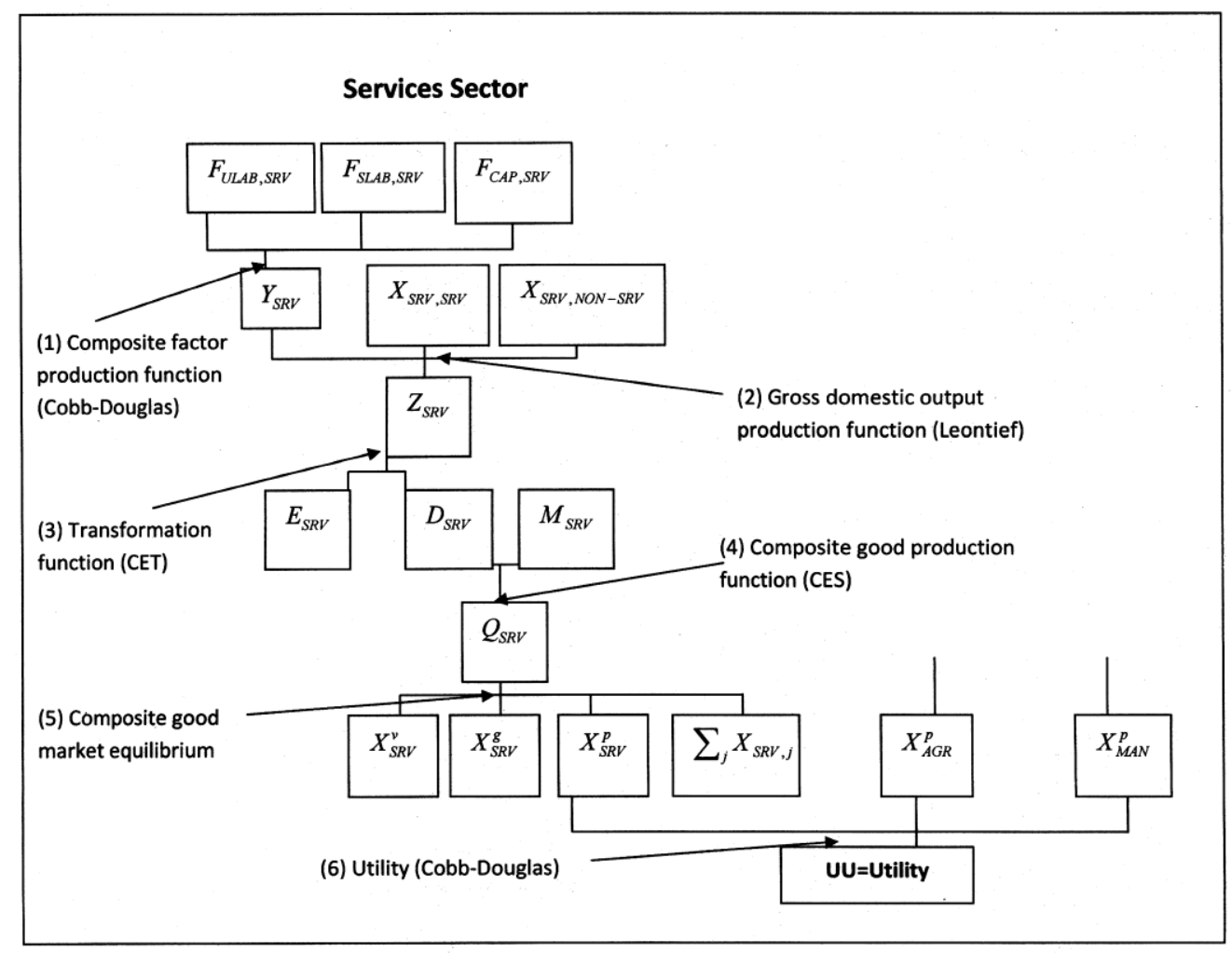

Figure 01: Structure of CGE Model

\subsection{Calibration}

The model has been calibrated using Sri Lanka social accounting matrix (SAM). A SAM is a matrix representation of the flows of all economic transactions that take place within an economy for single year providing static picture of the economy. The SAM that I use in this paper has been obtained from global trade analysis project (GTAP) database. This project is a global network of researchers whose conduct analysis on international trade policy issues (See Hertel (1997) for more details). The base year for this Sri Lankan SAM is year 2000. According to my knowledge, this is the latest SAM currently available for Sri Lanka. All the parameters and initial values for the variables used in the model have been calibrated using this SAM. The detailed SAM is shown in table 2. (Appendix) I have used the general algebraic modeling system (GAMS) computer software for the computation of the CGE model. GAMS is originally developed by the World Bank and widely used to solve CGE models. 
Table 1: Description of Model

\begin{tabular}{|l|l|}
\hline \multicolumn{1}{|c|}{ Variable } & \multicolumn{1}{c|}{ Description } \\
\hline$F_{C A P, S R V}$ & Capital used in Service sector \\
\hline$F_{S L A B, S R V}$ & Skilled Labor used in Service sector \\
\hline$F_{U L A B, S R V}$ & Un-Skilled Labor used in Service sector \\
\hline$Y_{S R V}$ & Composite factor of Service sector \\
\hline$Y_{N o n-S R V}$ & Composite factor of non-service sector \\
\hline$X_{S R V, S R V}$ & Intermediate Service sector products used in Service sector \\
\hline$X_{N o n-S R V, S R V}$ & Intermediate non-service sector products used in service sector \\
\hline$X_{S R V, N o n-S R V}$ & Intermediate service sector products used in non-service sector \\
\hline$X_{N o n-S R V, N o n-S R V}$ & Intermediate non-service products used in non-service sector \\
\hline$Z_{S R V}$ & GDP of service sector \\
\hline$Z_{N o n-S R V}$ & GDP of non-service sector \\
\hline$E_{S R V}$ & Exports of Service sector products \\
\hline$E_{N o n-S R V}$ & Exports of non-service sector products \\
\hline$D_{S R V}$ & Service sector products for domestic usage \\
\hline$D_{N o n-S R V}$ & Non-service sector products for domestic usage \\
\hline$M_{S R V}$ & Imports of service sector products \\
\hline$M_{N o n-S R V}$ & Imports of non-service products \\
\hline$Q_{S R V}$ & Armington's composite Service sector goods \\
\hline$Q_{N o n-S R V}$ & Armington's composite non-service sector goods \\
\hline$X_{S R V}^{v}$ & Investment of service sector goods \\
\hline$X_{N o n-S R V}^{v}$ & Investment of non-service goods \\
\hline$X_{S R V}^{g}$ & Government consumption of service sector goods \\
\hline$X_{N o n-S R V}^{g}$ & Government consumption of non-service goods \\
\hline$X_{S R V}^{p}$ & Household consumption of service goods \\
\hline$X_{N o n-S R V}^{p}$ & Household consumption of non-service goods \\
\hline & \\
\hline
\end{tabular}

\section{Results}

Several policy experiments have been simulated using both perfectly competitive market model and monopoly supplier market model. First, I examine the macroeconomic impact of the reduction of production tax rate in the service sector. Second, I examine the macroeconomic impact of import tariff rate increase in the service sector. In each policy simulation scenario, I examine the effects on several macroeconomic impact variables. They are overall output of the service sector, imports of the service sector, exports of 
the service sector, and the social welfare. The social welfare is measured by using Hicksian equivalent variation (EV) (Hicks 1939).

\subsection{Macroeconomic Impacts of}

\section{Production Tax Rate}

Reduction in the Service

\section{Sector}

I have conducted two simulations of tax rate reduction scenarios in the service sector. In the scenario (a), service sector production tax rate reduce by $5 \%$ compares to base case scenario. In the scenario (b), service sector production tax rate reduce by $10 \%$ compares to base case scenario. Table 3 presents the macroeconomic impact results of these two scenarios separately for perfectly competitive market economy and monopoly supplier market economy.

\subsection{Macroeconomic Impacts of Import Tariff Rate Increase of Service Sector}

Next I conducted two simulation scenarios of increase of import tariff in the service sector. First scenario is an increase of service sector import tariff by $5 \%$ compares to base case. Second scenario is an increase of import tariff by $10 \%$ compares to base case. Table 4 shows the results for these two scenarios under the perfectly competitive market economy and monopoly supplier market economy.

\section{Discussion}

Simulation results in the table 3 indicate that reduction of the service sector production tax rate by $5 \%$ will increase service sector gross output by $0.21 \%$ under the perfectly competitive market of service sector suppliers. However, under the monopoly supplier market economy, the service sector output increase by $0.61 \%$. Thus, the impact is approximately three times higher under the monopoly supplier market economy. These values seem to have approximately doubled when tax rate reduced by $10 \%$. The imports of service sector output seem to reduce with the reduction of production tax rates in both perfectly competitive market and monopoly supplier market models as local production cost become low under the new tax policy. Moreover, production tax reduction appears to have positively correlated with service sector exports. For instance, results indicate that $10 \%$ decrease of production tax in the service sector increase service sector exports by $2.08 \%$ in the perfectly competitive market economy and $3.88 \%$ in the monopoly supplier market economy. 
Table 3: Macroeconomic impacts of production tax policies (\% change to base case)

\begin{tabular}{ccccc}
\hline & $\begin{array}{l}\text { Scenario (a) } \\
\text { Service Sector Production } \\
\text { tax rate reduce by 5\% }\end{array}$ & $\begin{array}{l}\text { Scenario (b) } \\
\text { Macroeconomic } \\
\text { Variable }\end{array}$ & $\begin{array}{c}\text { Perfectly } \\
\text { tax rate reduce by 10\% }\end{array}$ \\
\cline { 2 - 5 } $\begin{array}{c}\text { Competitive } \\
\text { Market } \\
\text { Model }\end{array}$ & $\begin{array}{c}\text { Supplier } \\
\text { Market } \\
\text { Model }\end{array}$ & $\begin{array}{c}\text { Perfectly } \\
\text { Competitive } \\
\text { Market } \\
\text { Model }\end{array}$ & $\begin{array}{c}\text { Monopoly } \\
\text { Supplier } \\
\text { Market } \\
\text { Model }\end{array}$ \\
$\begin{array}{c}\text { Service sector } \\
\text { output }\end{array}$ & 0.209 & 0.612 & 0.428 & 1.194 \\
$\begin{array}{c}\text { Service sector } \\
\text { imports }\end{array}$ & -0.719 & -1.814 & -1.469 & -3.516 \\
$\begin{array}{c}\text { Service sector } \\
\text { exports }\end{array}$ & 1.009 & 1.971 & 2.080 & 3.877 \\
Social Welfare(EV) & 60.961 & 62.669 & 125.250 & 122.271 \\
\hline
\end{tabular}

Source: Author's simulation results

Table 4: Macroeconomic impacts of import tariff policies (\% change to base case)

\begin{tabular}{|c|c|c|c|c|}
\hline \multirow{2}{*}{$\begin{array}{l}\text { Macroeconomic } \\
\text { Variable }\end{array}$} & \multicolumn{2}{|c|}{$\begin{array}{l}\text { Scenario (a) } \\
\text { Service Sector import tax } \\
\text { rate increase by } 5 \%\end{array}$} & \multicolumn{2}{|c|}{$\begin{array}{l}\text { Scenario (b) } \\
\text { Service Sector Import tax } \\
\text { rate increase by } 10 \%\end{array}$} \\
\hline & $\begin{array}{c}\text { Perfectly } \\
\text { Competitive } \\
\text { Market } \\
\text { Model }\end{array}$ & $\begin{array}{l}\text { Monopoly } \\
\text { Supplier } \\
\text { Market } \\
\text { Model }\end{array}$ & $\begin{array}{c}\text { Perfectly } \\
\text { Competitive } \\
\text { Market } \\
\text { Model }\end{array}$ & $\begin{array}{c}\text { Monopoly } \\
\text { Supplier } \\
\text { Market } \\
\text { Model }\end{array}$ \\
\hline Service sector output & 0.473 & 0.758 & 0.895 & 1.408 \\
\hline $\begin{array}{l}\text { Service sector } \\
\text { imports }\end{array}$ & -8.186 & -11.894 & -15.428 & -22.052 \\
\hline $\begin{array}{l}\text { Service sector } \\
\text { exports }\end{array}$ & -0.167 & 0.083 & -0.322 & 0.138 \\
\hline Social Welfare(EV) & -32.690 & -16.496 & -62.610 & -31.369 \\
\hline
\end{tabular}

Source: Author's simulation results

Reduction of service sector production tax provides an incentive to produce more service sector products locally. It seems that excess service sector products can export to rest of the world. Moreover, the larger the reduction of production tax rate on service sector, the higher the service sector exports to rest of the world. More importantly, the reduction of production tax rate in service sector seems to increase the social welfare (Hicksian equivalent variation: $\mathrm{EV})$. This increase will be higher under the monopoly supplier 
market economy than the perfectly competitive market economy when tax rate is reduced by $5 \%$. However, if we reduce service sector production tax by $10 \%$, social welfare increase seem to be lower under the monopoly supplier market economy than the perfectly competitive market economy. This may imply that if production tax rate is relatively low, then some of the monopoly rent will be taken by the producers under the imperfect supply conditions. However, higher reduction of production tax rate in the service sector will generate higher social welfare under both perfectly competitive and monopoly supplier market economies.

According to the simulation results in table 4 , an increase of import tariff in the service sector by $5 \%$, service sector gross output will be increased by $0.47 \%$ under the perfectly competitive market economy and $0.76 \%$ under the monopoly supplier market economy respectively. These values have approximately doubled when the import tariff rate doubled from $5 \%$ to $10 \%$. Apparently, import tariff on service sector provide an incentive to domestic service sector producers to produce more service sector products because price competition will be lower when production sector import tariff increase.
Furthermore, service sector imports will be declined as expected in both perfectly competitive market and monopoly supply market economies. However, result also indicates that service sector exports increase only under the monopoly supplier market economy. Finally, social welfare seems to be decreased due to the increase of import tariff in both perfectly competitive market economy and monopoly supplier market economy. Moreover, Social welfare decrease is higher under the perfectly competitive market economy. For instance, $10 \%$ increase of service sector import tariffs reduces the social welfare by 62.61 points under the perfectly competitive market economy. However, $10 \%$ increase of service sector import tariffs only decreases 31.37 points under the monopoly supplier market economy. Therefore, import tariff increase seems to have less negative impact on social welfare when the service sector market is imperfect.

\section{Conclusion}

This paper examined the impacts of production tax and import tariff reform policies in the Sri Lankan service sector on a general equilibrium framework. Several policy experiments have conducted by assuming both perfectly competitive market economy and 
monopoly supplier market economy. Policy simulation results imply that reduction of service sector production tax increases the output of the service sector in both perfectly competitive market economy and the monopoly supplier market economy. Moreover, social welfare also seems to improve in both cases with the reduction of service sector production tax rate. The results also indicate that increase of import tariff in the service sector increase the service sector total output. However, social welfare has decreased significantly owing to increase of service sector import tariffs.

The production tax reform policies in the service sector seem to be a better policy option to improve Sri Lankan service sector compare to service sector import tariff reform policies. Current Sri Lankan government has recognized the importance of service sector to archive rapid economic development in Sri Lanka. Therefore, as a one of the efficient policy reform option, Sri Lankan government can reduce service sector production taxes to stimulate the Sri Lankan service sector. It is expected that production tax reforms not only increase the total output of service sector but also increase the social welfare in the society.

\section{References}

Amarasinghe, D \& Jayathilake, SB 2005, Input Output table for Sri Lanka (2005), Macroeconomic Policy Series no. 16, Institute of Policy Studies, Sri Lanka.

Ansari, MI 1995, 'Explaining the service sector growth: An empirical study of India, Pakistan, and Sri Lanka', Journal of Asian Economics, vol. 6, no. 2, pp. 233-246.

Armington, P 1969, 'A Theory of Demand for Products Distinguished by Place of Production', IMF Staff Papers, vol. 16 , no. 1, pp. 159-178.

Brown, M, Maurer, MR, Pak, T, Tynaev, N 2009, 'The impact of banking sector reform in a transition economy: Evidence from Kyrgyzstan', Journal of Banking \& Finance, vol. 33, no. 9 , pp. 1677-1687.

Central Bank of Sri Lanka 2004, The Consumer Finances and Socioeconomic Survey Report 2003/04-Part I, viewed15 August 2011, <http://www.cbsl.lk/cbsl/cfs03_04.htm.

Central Bank of Sri Lanka 2009, Annual Report 2009, viewed 11 January 2011, $<$ http://www.cbsl.gov.lk/pics_n_docs/10 
_pub/_docs/efr/annual_report/ar2009e/a r09_content_2009_e.htm/>.

Central Bank of Sri Lanka 2010, Recent Economic Developments: Highlights for 2010

and Prospects for 2011, viewed 11 January 2011, <http:// www.cbsl.gov.lk /pics_n_docs/10_pub/_docs/efr/recent_e conomic_development/Red2010/Red20 10e/red_2010e_index.htm>.

Dilek, O 2002, 'The distribution of foreign direct investments in the service sector in Istanbul', Cities, vol. 19, no. 4, pp. 249-259.

Eichengreen, B \& Gupta, P 2011, 'The service sector as India's road to economic growth', NBER Working Paper, no. 16757.

Gooroochurn, N \& Milner, C 2005, 'Assessing Indirect Tax Reform in a Tourism- Dependent Developing Country', World Development, vol. 33, no. 7, pp. 1183-1200.

Government of Sri Lanka 2010, Mahinda chintana 2010 - The vision ahead, viewed 10 June 2011,

<http://www.priu.gov.lk/mahindachinth ana/mahinda_chintana_brighter_future_ eng.pdf>.
Hertel, TW (ed.) 1997, Global trade analysis: modeling and applications, Cambridge University Press.

Hicks, JR 1939, Value and capital: An inquiry into some fundamental principles of economic theory, Clarendon Press, Oxford.

Hosoe, N, Gasawa, K \& Hashimoto, H 2010, Textbook of Computable General Equilibrium Modeling. Programming and Simulations. Palgrave Macmillan, England.

Rajapathirana, S 1988, 'Foreign Trade and Economic Development: The Case of Sri Lanka', World Development, vol. 16 , no. 10 , pp. 1143-1157.

Somaratne, WG 1998, 'Policy Reforms and the Environment: General Equilibrium Analysis of Land Degradation in Sri Lanka', Unpublished $\mathrm{PhD}$ Thesis, School of Business, Latrobe University, Bundoora, Australia.

Sri Lanka Department Statistics 2009, Sri Lanka National Accounts.

Sri Lanka Ministry of Finance and Planning 2010, Government Budget Speech 2011, viewed 10 June 2011, <http://www.treasury.gov.lk/docs/budge t2011/budgetspeech2011-eng.pdf>. 
Verma, R 2006, 'India's Service Sector Growth - A “New” Revolution', paper presented to the Dynamics, Economic Growth, and International Trade conference, Kiel, Germany.
Xiaoqing, F \& Shelagh, H 2009, 'The effects of reform on China's bank structure and performance', Journal of Banking \& Finance, vol. 33, no. 1, pp. 39-52.

\section{APPENDICES}

Table 2: Sri Lankan Social Accounting Matrix (values are in millions of Rupees)

\begin{tabular}{|c|c|c|c|c|c|c|c|c|c|c|c|c|}
\hline & $\begin{array}{l}\text { AG } \\
\text { R }\end{array}$ & $\begin{array}{l}\text { MA } \\
\mathrm{N}\end{array}$ & SRV & CAP & $\begin{array}{l}\text { SLA } \\
\text { B }\end{array}$ & $\begin{array}{l}\text { ULA } \\
\text { B }\end{array}$ & IDT & $\begin{array}{l}\text { TR } \\
F\end{array}$ & $\begin{array}{l}\mathrm{HO} \\
\mathrm{H}\end{array}$ & $\begin{array}{l}\text { GO } \\
\text { V }\end{array}$ & INV & EXT \\
\hline AGRICULTU & 228. & 510. & 207. & 911. & 1406 & 1450 & 182. & 73. & & & & 403. \\
\hline $\mathrm{RE}$ & 6 & 6 & 0 & 8 & .9 & .8 & 1 & 1 & & & & 6 \\
\hline MANUFACT & 1606 & 5426 & 1929 & 3283 & 901. & & & 532 & & & & 7911 \\
\hline \multirow[t]{2}{*}{ URE } & .9 & .2 & .4 & .4 & 9 & & 12.0 & .2 & & & & .8 \\
\hline & & 2461 & 4017 & 4692 & 4818 & & 1731 & & & & & 1145 \\
\hline \multirow[t]{2}{*}{ SERVICE } & 76.7 & .1 & .7 & .4 & .5 & & .3 & & & & & .1 \\
\hline & & & & & & & & & 8887 & & & \\
\hline CAPITAL & & & & & & & & & .7 & & & \\
\hline SKILL & & & & & & & & & 7127 & & & \\
\hline LABOR & & & & & & & & & .2 & & & \\
\hline UNSKILL & & & & & & & & & 1450 & & & \\
\hline LABOR & & & & & & & & & .8 & & & \\
\hline INDIRECT & & & & & & & & & & 1925 & & \\
\hline \multirow[t]{2}{*}{ TAX } & & & & & & & & & & .5 & & \\
\hline & & & & & & & & & & 605. & & \\
\hline TARIFF & & & & & & & & & & 2 & & \\
\hline HOUSEHOL & 2549 & 5733 & 7186 & & & & & & & 1371 & 624. & \\
\hline $\mathrm{D}$ & .4 & .9 & .6 & & & & & & & .6 & 2 & \\
\hline GOVERNME & & 255. & 1353 & & & & & & & & 2257 & \\
\hline NT & 35.3 & 7 & .7 & & & & & & & & .6 & \\
\hline INVESTMEN & & 1961 & 2872 & & & & & & & & & \\
\hline \multirow[t]{2}{*}{$\mathrm{T}$} & 87.1 & .7 & .0 & & & & & & & & & \\
\hline & 790. & 5254 & 1376 & & & & & & & & 2039 & \\
\hline EXTERNAL & 4 & .6 & .4 & & & & & & & & .0 & \\
\hline
\end{tabular}

Source: Global Trade Analysis project (GTAP) database 